\title{
The 1873 Election in Hawai'i between Prince William Charles Lunalilo and the Other Candidate
}

TIFFANY ING-TSAI

While He LAY on his deathbed on the morning of December 11 , 1872, Lot Kapuāiwa, King Kamehameha V, was called upon to perform one last duty as mō‘ì (king). Attorney General Stephen H. Phillips and Governor John O. Dominis implored Kapuāiwa to name his successor. A few names came up. Bernice Pauahi Bishop refused the title despite the mō‘ı̄’s insistence, and Kapuāiwa turned down Pauahi's recommendations of Ruth Ke'elikōlani and Queen Emma. ${ }^{1}$ Unfortunately, Kapuāiwa died before he selected a successor. The Constitution of 1864, the one Kapuāiwa created to replace Kauikeauoli, King Kamehameha III's 1852 Constitution, mandated that if a sovereign failed to name a successor the next mō'ī would be decided by legislative vote. Thus, Kapuāiwa's passing marked a new epoch in Hawai'i's history. For the first time, the legislature would decide who would reign as king.

This article focuses on that 1873 election as documented by the newspapers printed in Hawai'i during that time. Mainstream

Tiffany Lani Ing Tsai, from Mānoa, O‘ahu has a Ph. D. in English from The University of Hawai'i at Mānoa. Her dissertation, "Ka Ho'omālamalama 'ana i nā Hō'ailona o ka Mō‘ Kalākaua a me kona Noho Ali`i 'ana: Illuminating the American, International, and Hawai' $i$ Representations of David Kalākaua and his Reign, I874-I89I, "was awarded the 2015 Biography Prize by the University of Hawai'i at Mānoa Center for Biographical Research. An earlier version of a section was published in the 2014 edition of The Hawaiian Journal of History.

The Hawaiian Journal of History, vol. $5^{\mathrm{o}}$ (2016) 
English-language narratives about the 1873 election, such as Ralph S. Kuykendall's Hawaiian Kingdom vol. 2: Twenty Critical Years, present maka'āinana support for William Charles Lunalilo as one-dimensional. ${ }^{2}$ By utilizing a broader range of resources, this account provides a more nuanced sense of native and non-native backing for Lunalilo. In particular, this article will show how maka'äinana and editors used the newspapers as a venue to publish their early united support for Lunalilo. Support of Lunalilo in light of his proposal to restore the $185^{2}$ Constitution can also be seen in the English-language Pacific Commercial Advertiser (PCA). Finally, this article will show that while Kapuāiwa's death left the kingdom perplexed as to a successor, the newspapers' reports of Hawai'i's first election demonstrate how a confident Lunalilo coolly settled into his title as mōii long before the votes were cast.

\section{The Candidates to Succeed Kapuāina}

Albert Francis Judd, who served in both the House of Representatives and the House of Nobles beginning in 1868, remembered how he "called upon [Lunalilo] the morning the King died, and told him that the Nation naturally looked up to him as the probable next King." ${ }^{3}$ This was surprising, because during his political career as a noble and representative, prior to ascending the throne, Lunalilo had been described as "having had the cold shoulder given him by the late Kings, and never having been entrusted with any Government responsibility." ${ }^{4}$ Both Kamehameha IV and Kamehameha V disliked Lunalilo, prohibited his courting of their sister, Victoria Kamāmalu, and limited his government experience under their reigns. ${ }^{5}$ Judd himself continued by noting, "Lunalilo was from mere boyhood addicted to the excessive use of intoxicating drinks." ${ }^{6}$ The chief's problem with alcohol was particularly serious. Lili 'uokalani made clear that "there were grave reasons" why Lunalilo was an "injudicious" choice as successor, and that at the time of Kapuāiwa's death, Charles Reed Bishop was Lunalilo's guardian, apportioning \$25 per month to the prince as a result, in part, of his land being "out of his own control." " For this reason, although Lunalilo and Kalākaua were the main competitors for the title of $\overline{m o}^{\prime} \overline{1}$ in 1873 , the names Pauahi, Ke'elikōlani, and Queen Emma also appeared on the ballot. ${ }^{8}$ 
Nevertheless, Lunalilo's high-ranking lineage, which linked him to Kamehameha I, and his official title as prince, which will be discussed in this article, appealed to most native voters because the Kamehamehas were mō'ī . ${ }^{9}$ In Hawaii’s Story by Hawaii’s Queen, Lili‘uokalani confirms that "The foremost candidate for the vacancy was undoubtedly the king's first cousin, Prince William Lunalilo; and in the matter of birth nothing could be said adverse to his claim." 10 Through his grandfather Kala'imamahū, the half-brother of Kamehameha I, Lunalilo was the grandnephew of the great mō'ì. He was also the son of the former kuhina nui (prime minister or premier), Kekāuluohi, and his father was William Charles Kana'ina, a kaukauali'i (chief whose father was a high chief and mother was a low chief) who became a noble, privy councilor, and Supreme Court justice, and who also managed the 400,000 acres that Lunalilo inherited from Kekāuluohi upon her death. The singular, overarching importance of a successor's genealogy to nineteenth-century Kānaka 'Ōiwi is more obvious in this first election than in the second one that would take Kalākaua to the throne, because even though almost everyone knew that Lunalilo had a serious drinking problem, within a few weeks of Kapuāiwa's death the prince had, in effect, secured his victory by virtue of his bloodline and title. ${ }^{11}$

The Newspapers in Hawai'i in 1872 ANd 1873

Hawai'i's newspapers provide additional information for understanding the 1873 election. There were four major newspapers from December 1872 to January 1873 , Ka Nupepa Kuokoa, Ke Au Okoa, the Pacific Commercial Advertiser, and The Hawaiian Gazette. The Hawaiianlanguage Ka Nupepa Kuokoa was edited by American loyalist Henry Martyn Whitney but published for Native Hawaiians. Kuokoa contained important native mo'olelo (stories), mele (songs or chants), and other cultural records. Printed for sixty-six years, 1861-1927, Kuokoa had the longest publication run of any Hawaiian-language newspaper in Hawai' $i$, confirming the viability of a Hawaiian readership. Ke Au Okoa was edited by independent nationalist John Makini Kapena as one of the official government newspapers. The Englishlanguage $P C A$, under owners James Auld and James H. Black and editors William L. Green and Henry L. Sheldon, was pro-American 
and supported business, much of which was owned by non-natives in Hawai'i. Many in that group looked at Lunalilo as an artery to government power. Finally, The Hawaiian Gazette $(H G)$, under editor John Mott-Smith, served as the other official kingdom newspaper until $1873 \cdot{ }^{12}$ A careful, page-by-page search through the four newspapers from December 14, 1872 to January 15, 1873 identified 82 articles that significantly addressed the election. The first article appeared in Kuokoa on December 14, 1872, just three days after Kapuāiwa's death. Whitney acted fast. "Ko Kakou Kulana i keia Wa" ["Our Position at this Time"], half of a column in length, claimed that Lunalilo was the only chief who could succeed Kamehameha V: "Hookahi wale no alii kane kiekie e ola nei, oiai ma kona hanau ana a me kona moolelo, ua noonooia he hooilina kupono no ke Kalaunu o na Kamehameha-a oia no hoi Ka Mea Kiekie Ke Alii W. C. Lunalilo"13 [There is only one high chief living, according to his birth and his lineage. Considered a rightful successor to the Crown of the Kamehamehas-he is The High Chief W. C. Lunalilo]. The last article in this span appeared in the $H G$ on January 15,1873 , and was one column in length, covering Lunalilo's swearing-in ceremony at Kawaiaha'o Church.

Beginning from day one and continuing over the span of one month and one day, the four newspapers were unanimous in their support for Lunalilo. He was their early favorite-perhaps the only choice to succeed Kapuāiwa. The first few newspaper articles reported the impudent timing of some of the people's behavior just days after Kapuāiwa had passed; specifically, in meetings prearranged to mourn Kapuāiwa, people were bypassing mourning protocols to announce publicly their choice for the successor. ${ }^{14}$ In a meeting held at Kaumakapili Church the day after Kapuāiwa's passing, for instance, Native Hawaiians gathered to mourn collectively the death of their mō' 1 and express their condolences to his sister Ke'elikōlani. Amid the speeches, however, "ua kuhihewa kekahi poe" [some people mistakenly thought] the object of the meeting was to discuss the selection for the "Moi hou" [new King] and "Ua kukala akea ae kekahi poe maloko o ua halawai la e koho ia Ka Mea Kiekie Lunalilo i Moi"15 [some people publicly proclaimed in the meeting to elect His Excellency Lunalilo as King] even during a time officially set aside for mourning. When those people realized the meeting was 
not to offer their selections for a new sovereign, they left the church. Kuokoa reported that similar scenes occurred at two other native mass meetings organized to grieve Kapuāiwa's passing on December 17 and $26 .{ }^{16}$ The newspapers, therefore, reported the people's eager anticipation of a new king even during a time reserved for mourning the former one, and although some may say it was a little too soon, those people knew exactly who they wanted to lead them, and made that wish known. ${ }^{17}$

On December 16, to show his natural right to the throne, Lunalilo issued a manifesto in Hawaiian and English, announcing his candidacy and proclaiming the kingdom's first plebiscite, to be held on January 1, 1873. Although Lunalilo had not yet been elected mōiî, he was behaving as though he had. Kapuāiwa's 1864 Constitution made no mention of a plebiscite. The prince explained that "in order to preserve peace, harmony and good order" and allow the "voice of the People to be freely and fairly expressed," male subjects in the kingdom should be allowed to choose the next king. As Jonathan Kay Kamakawiwo'ole Osorio has pointed out, in one swoop, Lunalilo effectively dismissed the 1864 Constitution and reverted back to the $185^{2}$ Constitution. ${ }^{18}$

On December 21, the PCA printed Lunalilo's recommendation to the representatives from the districts throughout the kingdom that on January 8 they be sure to vote according to their constituents' expressed wishes:

If any officer or officers of any election district shall refuse to act in accordance herewith, or if there shall be a vacancy in said offices in any district, the people may choose others in their places, who may proceed in conformity to law in conducting the election. ${ }^{19}$

Days later, Lunalilo sent another address to the nation recommending that the people gather in their districts to select officials to oversee the elections. ${ }^{20}$

After the newspapers ran Lunalilo's announcement, their support for him continued, never skipping a beat. The papers also documented native backing in a string of meetings held at Kaumakapili Church in support of Lunalilo, ${ }^{21}$ and endorsements from Kona, Waialua, and 'Ewa on $\mathrm{O}$ 'ahu, Lahaina on Maui, Waimea, Kōloa, 
and Nāwiliwili on Kaua'i, and Moloka'i. ${ }^{22}$ Kuokoa also printed eleven short news items from $\mathrm{O}^{\prime}$ ahu detailing further maka'āinana support of Lunalilo. ${ }^{23}$ Then, on December 19, Ke Au Okoa published a statement from those of Ko'olaupoko, $\mathrm{O}^{\prime} \mathrm{ahu}$, proclaiming three reasons they would vote for Lunalilo: "kona naauao" [his intelligence], "kona kokua nui mamuli o na makaainana iloko o na Kau Ahaolelo i hala e aku" [his tremendous support of the people in the past Legislative sessions], and "kona inoa hanohano, nani a me ka hoalii ana" ${ }^{24}$ [his distinguished name, glorious and noble]. When Lunalilo was baptized in his infancy, his father Charles Kana 'ina sought to name him after himself, William Charles Kana'ina, but Kekāuluohi interjected: "'He is the highest chief in all the islands, therefore his name shall be Luna-lilo' ('above all')." ${ }^{25}$ Up to this point in the election, support of Lunalilo had saturated the newspapers, demonstrating a united endorsement of the prince, like this report from a December 17 mass meeting in Hau'ula, Ko'olauloa, O'ahu, where "ua hooholo lokahi lakou, o ka Mea Kiekie ke Keiki Alii William C. Lunalilo, oia ka Moi e koho aku ai" ${ }^{26}$ [they unitedly determined that His Highness the Prince William C. Lunalilo was the one to elect as King]. The papers also reported that residents of Wailuku and Makawao, Maui, and Ka' $\bar{u}$, Hawai'i supported Lunalilo.

Each published account of the people's support for Lunalilo became a record that in a sense simultaneously announced and preserved their votes for all readers, and especially the lunamaka'ainana (representatives), to see. The $H G$ confirmed Lunalilo's lead this way: "There is not a member of that august body who has the slightest possible doubt as to the person on whom their choice should fall. Their constituents have spoken their preference in language too unanimous to be misunderstood, too emphatic to be unheeded." ${ }^{27}$ And this article title from the $P C A$ told readers all there was to know: "The Prince: Enthusiastic Meeting at Kaumakapili Church-Prince W. C. Lunalilo the People's Choice-Tremendous Cheering-Representatives Unanimously Instructed to Vote for Prince Lunalilo and No One Else." 28

On its December 28 front page, Kuokoa also displayed the support of noted native historian Samuel M. Kamakau for Lunalilo: "E ola ka Moi! E ola ka Moi!! E ola ka Moi Ke Keiki Alii ka Mea Kiekie William C. Lunalilo i ke Akua" ${ }^{29}$ [Long Live the King! Long Live the King!! 
God save the King, His Royal Prince Highness William C. Lunalilo]. And in the same issue, just four days before the January 1 election, Kuokoa published four reasons Lunalilo should be king: first, "no kona pili loa i na imi hale noho aupuni" [his very close lineage to the [Kamehameha] dynasty]; second, "no kona kapukapu alii no ke hele mai i na wa a pau, aole e like me kekahi poe e ae ka moalaala" [his chiefly dignity at all times, unlike some other people who gad about]; third, "no ka mea, oia wale no ka inoa Keiki Alii e ola nei, a i hookohuia mai aohe mea e ae" [because he is the only living one entitled Prince, and designated as such there are no others]; and fourth, "no kona kokua mau [la] i na makaainana i na Kau Ahaolelo a pau. Ma na hoemi auhau kaumaha o ka lahui, oia ka hikimua ma ka aoao o na alii" ${ }^{30}$ [his continuing support of the people in all the Legislative Sessions. In reducing the heavy taxes on the people, he is foremost of the nobles]. Lunalilo was known for behaving as a noble, and the native press emphasized his unchanging dignity as well as his official designation as prince. ${ }^{31} \mathrm{Ke} A u$ Okoa and Kuokoa claimed that the title implied Lunalilo's competence, with Kuokoa linking it to the prince's work advocating on the people's behalf. Although David Kalākaua was running against Lunalilo, Ke Au Okoa simply referred to Kalākaua as "kahi mea okoa e ae"32 [the other candidate]. On December 28, a pamphlet written by Kalākaua and addressed to maka'āinana was circulated about Honolulu. In it, Kalākaua spoke to Kānaka Maoli and asserted his own royal lineage and part in the making of Hawai'i nei:

E na muli o Keaweaheulu, o Kameeiamoku a me Kamanawa. Ua kahe mua ko kakou koko a ua eha ka ili no ka imi ana i ka Hale a me ka loaa ana o ka maluhia o keia noho ana. Na kakou i kukulu keia Aupuni. ${ }^{33}$

[O descendants of Keaweaheulu, Kame'eiamoku, and Kamanawa. Our blood has flowed and our skins have suffered in seeking the Royal House and obtaining peace for this realm. We are the ones who built this Kingdom.]

Kalākaua also reproved Lunalilo for announcing the plebiscite during the time set aside to mourn Kapuāiwa's passing and condemned those who insulted Kapuāiwa: "I ka ike aku i na hana ua hanaia mai nei no ka kakou Moi Lani Haku. Aole i nalo kona kino hiwahiwa, aia hoi, hoomaewaewa ia nei kona mau iwi" ${ }^{34}$ [Seeing the things that 
are being done to our King, our Heavenly Ruler. His beloved body is not buried and behold, his bones have been desecrated]. Finally, Kalākaua warned the people: "Mamuli o ke alakai hewa ana a na haole e miki nui nei, e lilo ia lakou ka hooponopono aupuni ke noho ae o W. C. Lunalilo i ka Nohoalii" ${ }^{55}$ [Because of the wrongful leadership of the foreigners who always ask for anything they see, they will reform the government should W. C. Lunalilo reign]. Kalākaua's attempts to warn Native Hawaiians about Lunalilo would be futile, as the January 8 legislative vote later proved.

There was such overwhelming support for Lunalilo that his victory was assured long before lunamaka'āinana would vote, at least according to the newspapers. The PCA called Lunalilo's proposal for a plebiscite "unselfish patriotism," since he already claimed himself to be the "rightful heir to the Throne." ${ }^{36}$ In fact, during the 1873 election Lunalilo became synonymous with the $185^{2}$ Constitution. ${ }^{37}$ His reversion to this deliberative process did more than appease those of the business element who desired more control of the government. Some businessmen also saw it as an opportunity to criticize publicly the former $\mathrm{mo}^{-} \overline{1}$ in the newspapers, a practice that was once taboo but would increase exponentially during Kalākaua's reign. As Osorio has pointed out regarding Kamehameha V, "There was no shortage of haole who were strongly opposed to so powerful a king," 98 and the $185^{2}$ Constitution would restore power to the people. The business element in Hawai'i had opposed Kapuāiwa for many reasons, including his refusal to appoint Americans to his cabinet, and his consolidation of power into his own hands, which reduced the rights of the nobles and legislators-essentially, those who the missionaries saw as "the people." Just three days after Kapuāiwa's passing, the $P C A$ felt safe to criticize Kapuāiwa's constitution and cabinet, and indirectly Kapuāiwa himself, ${ }^{39}$ claiming that now that he was dead so was his constitution, and many wrote to the PCA calling for a convention to restore the $185^{2}$ Constitution. ${ }^{40}$ As the January 8 election approached, foreign push for a constitutional convention intensified. Note the PCA's insistence here: "We repeat, the crisis now upon us is a perilous one, and the peril is no less than that if we do not awake to its imminency, and at once take determined and vigorous action in defense of our constitutional rights and liberties." 41 


\section{The January 1 Plebiscite}

In the early morning of January 1, 1873, excited crowds gathered in Honolulu for the plebiscite, and "at the place of voting everything was animated; speeches were made by several Hawaiians, all of whom possessed a flow of language that was astounding." 42 The PCA reported that in Honolulu "The polls at Adams' auction rooms were opened promptly at 8 o'clock A. M., and during the whole day the clerks were kept at the top of their speed recording the names of the seemingly endless string of citizens who were eager to deposit their ballots." 43 The turnout there was astounding: " 480 votes were registered the first hour, 2,200 by noon, and when the lists were closed at 5 o'clock P.M., the estimate gave 3 , ooo as the total number cast in the nine hours." ${ }^{4}$ Among the voters who turned out were "a long procession of Mormons from the other side of the island, and crowds of people from the most distant parts of the district." ${ }^{45}$ And at the poll's closing it was reported that "a dense crowd awaited the announcement of the result." ${ }^{46}$ Later, Kuokoa reported the kingdom-wide results of the January 1 election: Lunalilo received 1 1,847 votes. Ruth Ke'elikōlani, Pauahi's initial recommendation to Kapuāiwa, got 3o. Kalākaua and Emma received 12 and 9 votes respectively. Pauahi, Kapuāiwa's desire, won 1 vote. ${ }^{47}$ As for Kalākaua and Emma, they would run in the 1874 election following Lunalilo's unexpected death after a reign that lasted a little over a year. Ke Au Okoa had welcomed the people's opportunity to vote in the January 1 plebiscite:

He mea malihini a kamahao no iwaena o ka lahui e like me keia, no lakou na kupuna i maa a i kamaaina i ka hooponopono ana i ko lakou mau hoopaapaa me na maka ihe, ka pololu, a me ka palau. [ . . ] O ka pololu, na mea kaua, a me ka lala kino ikaika, oia ka mana a me ka lanakila o ka la i hala; aka, iloko o keia mau la, ua hoopalupaluia ia mau mea e ka pahu balota! ${ }^{48}$

[There is something unusual and remarkable amid this kind of people whose ancestors were accustomed to resolving their disputes with spear points, long spears, and clubs. [ . . . ] The long spear, weapons of war, and strong limbs were the power and victory in the past. However, these days, those things are softened by the ballot!] 
While the upcoming legislative vote on January 8 would determine who would be mō‘i, the $H G$ predicted that Lunalilo's victory was now certain, as he was the unanimous winner in every district throughout the kingdom. ${ }^{49}$

\section{The January 8 Legislative Election}

A week later, on January 8, members of the legislature met to vote. Newspapers reported that about 1 2,0oo drew near the Court House. Ke Au Okoa explained it this way: "Ua piha pu ka pa o ka Hale Hookolokolo, a me na alanui e kupuni ana, i ka haiamu, ka lehau, a me ka mumulu ana o na makaainana" [The grounds of the Court House and the surrounding streets were filled with great crowds of people and the swarming of people], adding "aole wale o ko ke kulanakauhale nei, aka, o ka poe kahi mai na kua mai, a ua hoopiha ae lakou i na alanui" [not merely those of the city, but the people from the country, they filled the streets]. More importantly, the people gathered "e like me ka hoopuka puwalu ana o na manao lokahi o ke 'Lii Lunalilo ka Moi” ${ }^{50}$ [unitedly proclaiming concerted wills for King Lunalilo]. Kuokoa and the PCA reported that some were armed with pistols and stones and there was yelling in favor of Lunalilo, and Ralph S. Kuykendall asserts that maka'āinana would have rioted if Lunalilo lost. ${ }^{51}$ Of those at the Court House Ke Au Okoa reported:

E kaunui ana ko lakou mau maka, a e koii aku ana hoi ko lakou mau manaolana ana o ka hookoia o ko lakou mau anoai lahui, o ka puanaia mai o ka Lani Lunalilo ka Moi! $!^{52}$

[Their eyes were fixed, and their nationalist expectations were yearning to be fulfilled through the announcement that The Heavenly One, Lunalilo, is the King!]

Someone had written on pieces of paper: "E Ola Mau Loa Ko Kakou Moi William C. Lunalilo! O W. C. Lunalilo Ka Moi A Na Puuwai!"53 [Long Live our King William C. Lunalilo! W. C. Lunalilo, The King of Hearts!] Ke Au Okoa observed that when Lunalilo made his way to the courthouse:

Ua haehae ia ae la na ao kaalelelewa e na hipa hipa huro o ka hauoli a me ka lokahi o ka Lani Lunalilo ka Moi! He mea makehewa i ka maka 
peni ke hahai aku, aohe no hoi e loaa na huaolelo, a aohe no hoi he puana ana e hiki ai ke hoike aku i ka ulumahiehie lokahi o ka lahui hauoli! $!^{54}$

[The floating clouds were torn asunder by the glorious and joyous hip, hip, hoorays for The Heavenly One, King Lunalilo! It is something impossible for the pen to describe, indeed there are truly no words and indeed no utterance that can illustrate the united appearance of the joyous people!]

When it was announced that William Lunalilo was the new mō'i ${ }^{1}$ there was cheering from the gathered people outside of the courthouse. Ke Au Okoa reported that a committee was sent to notify Lunalilo of his victory, and boasted again of maka'āinana unity: "Ua lokahi like loa na manao o ka lahui, e lilo Oia ka Moi o ko kakou Pae Aina aloha" 55 [The minds of the people were unanimous in Him becoming King of our beloved Archipelago]. The PCA reported that once the "immense concourse" caught sight of Lunalilo "the cheers were deafening." ${ }^{56}$ There was such excitement, "Men were seen running about half frantic with pleasurable excitement, shaking hands vigorously with everybody they met." ${ }^{57} \mathrm{Ke}$ Au Okoa pointed out that the legislature's voting according to the lāhui's desire was a victory for the people because lunamaka'āinana accurately represented the people of all the islands in the archipelago:

Ma keia la, ke hoomaikai aku nei makou ia kakou iho e ka lahui Hawaii, aole wale ma ke koho lokahi loa ia ana e ko kakou Ahaolelo, i waiho aku ai o ka mana ma ko kakou Kumukanawai:-aka, ua eo no i kela la aku nei ko kakou lanakila, ma ka hoili ana i ko kakou mau leo pawalu lokahi lahui: o Ka Mea Kiekie, ke Keiki Alii Williama Kale Lunalilo, ko kakou Moi. ${ }^{58}$

[Today, we congratulate ourselves, the Hawaiian nation, not just in the unanimous election by our Legislature, the authority for which was embedded in our Constitution:-but that our victory was secured that day in conveying our people's united, eightfold voices: His Excellency, The Prince William Charles Lunalilo, is our King.]

Ke Au Okoa praised maka'āinana for the "maluhia lokahi o ka leo o ka lahui" ${ }^{59}$ [peaceful unity of the voice of the people]. On Janu- 
ary 9, Samuela Uza, the secretary of the election in Hanalei, Kaua'i, reported some tampering with votes on the side of David Kalākaua, ${ }^{60}$ and on January 1 1, John Ross wrote to the PCA from Princeville, Kaua 'i, alleging that Kalākaua's agents were canvassing Hanalei promising favors to residents if they voted for Prince Kalākaua. ${ }^{61}$ Through that effort Kalākaua gained 145 votes in an informal election held on December 28 in Hanalei, whereby he beat out Lunalilo. ${ }^{62}$ However, it was later discovered that women, children, and non-naturalized Chinese made up some of those voters, so those votes were thrown out. In the January 1 plebiscite, Kalākaua acquired merely eight of Hanalei's votes whereas Lunalilo won 104 votes. ${ }^{63}$ The tampering scarred Prince Kalākaua's reputation.

Early on January 9, the "streets were alive with sight-seers" and maka'āinana began to fill Kawaiaha'o Church to witness their new king taking the oath to uphold the constitution. ${ }^{64}$ The $H G$ reported that "the Church was splendidly decorated with flowers and evergreens, and the platform upon which His Majesty was to take the Oath of Office, shone with the most beautiful flowers and bouquets." ${ }^{55}$ The newspapers reported that in total, about 3 ,ooo people had gathered in the church, on King Street, and within the palace's enclosure. It was recounted that "His Majesty's approach was heralded to those inside the church by the cheering of the great throng without." 66 The king first addressed the nobles and representatives in Hawaiian and English regarding the state of the kingdom and his pursuit toward immigration: "At home there is peace and reasonable prosperity, which it will be my earnest endeavor to promote. [The islands] have capacity enough to make a Kingdom which shall command the respect of other nations, as well as to give greater comfort and happiness to a far larger population." Toward increasing prosperity the king proclaimed: "We are fortunately placed by nature on the great Ocean Highway of Nations; the commerce of all flags should be attracted hither by the safety of our harbors, our abundant products, and liberal laws and regulations of our ports," and welcomed "All legislation in the future, having in view the proper protection and promotion of our commercial relations." ${ }^{67}$ Lunalilo then addressed maka'äinana in Hawaiian and English, speaking briefly and focusing on encouraging the people to increase the native population: 
History plainly teaches that no Nation can improve in population and wealth without industry and good morals. It is a fact, which oppresses my heart, that the Hawaiian population has been gradually diminishing for years, and I appeal to every Hawaiian, whether here or at his quiet home, to arise in full strength and stay this desolation. It can be done, but it will require the efforts of all who love Hawaii nei ${ }^{68}$

At the ceremony's conclusion the native choir sang "E Ola ka Mō'i i ke Akua" [God Save the King] and the king walked back to the palace while the crowd outside cheered. ${ }^{69}$

On January 1 1, following Lunalilo's victory, with greater boldness the PCA printed this statement from a letter: "We trust that our new King will rightly interpret the enthusiasm which has greeted his accession to the Throne, as the uprising of a people desirous of ridding themselves and their country of the incubus of an administration selfish in its motives and detrimental to the national prosperity in its policy." 70 The PCA's support of Lunalilo's restoration of voting rights to the people reflected the attempts of the business element in Hawai ${ }^{7}{ }^{71}$ to seize power in the legislature again. Lili'uokalani subsequently claimed that Lunalilo's "selection was chiefly due to the influence of the representatives of the single island of Oahu." And Judd remembered: "After a few days, public sentiment commenced to crystallize about him, and the best part of the Community rallied about, Kept him sober, and stayed up his hands." 72 Lili'uokalani concluded by saying that after those representatives' backing of Lunalilo was announced, it was "accepted with the usual cheerfulness and good faith displayed by the Hawaiian people, who have always been loyal subjects to any one of their own acknowl-

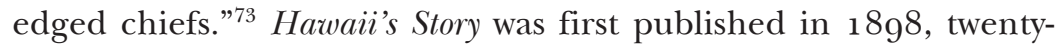
five years after the 1873 election; however, the queen's broader allegations here deserve consideration in light of the newspapers' accounts of the foreign movement to reclaim power in the legislature. Lili'uokalani noted that "on the accession of Lunalilo, this latter party [the missionary party, mentioned earlier] showed a determination to control the king, and by subjecting his weakness to their strength, to influence the fate of the Hawaiian people and the destiny of the Islands." ${ }^{\prime 4}$ The new king installed among others 
Edwin O. Hall and Albert F. Judd-those aligned with the missionary party-in his cabinet. Lili“uokalani remembered that the king's new cabinet was "distinctively American"; that is, "Seeking to render the Islands a mere dependency, either openly or under sufficient disguise, on the government of the United States" versus a direction "called Hawaiian," that looks to "the prosperity and progress of the nation as an independent sovereignty." 75 More importantly, according to Judd, the plebiscite surrendered Hawai'i's status as a monarchy over to a democracy. ${ }^{76}$ In that December 16 manifesto, Lunalilo further claimed that if elected he would restore voting rights to maka'āinana, and even denizens regardless of income and property ownership. ${ }^{77}$ Non-natives who were loyal to America, like those of the missionary party, particularly gravitated toward that promise. Osorio has said that Lunalilo may have sensed that to become king he needed the missionary-party legislators' votes just as much as they needed him to return power to the House. ${ }^{78}$

The election reveals a lot about Hawai'i's politics and people at that time. Foremost, most Hawaiians equated the mō'i’’s genealogy with his potential competence. The very first newspaper article of the election cycle had stated that because of Lunalilo's "hanau ana me kona moolelo" [birth and lineage] he is the "hooilina kupono" [rightful successor], and the Hawaiian- and English-language newspapers sustained this certainty until the prince's victory. Secondly, whereas at the moment of Kapuāiwa's death Lunalilo's name did not come up for succession, after three weeks the newspapers reported that he had gained the kingdom's unanimous vote for that title.

How could an ali'i, who was supposedly incapable of managing himself or his affairs, become the indisputable choice for mō' $\overline{1}$ among two groups of people who normally feuded? First, most Kānaka 'Ōiwi wanted Lunalilo because of his title as "keiki ali"i," or prince, his lineage to Kamehameha I, and his support of the lāhui-both characteristic of a mō'in. While Western epistemology often measures a leader's competence by his experience, intellect, and wisdom, under nineteenth-century Native Hawaiian ideology, one's official status and genealogy seemingly trumped them all. Most natives believed that the simple facts of Lunalilo's title as prince and his bloodline meant that he would inevitably rise to become a worthy mō' $\overline{1}$. One pamphlet from January 15, 1873 described such surety: 
And if a wonderful contrast is presented to men's minds between the position of but a few weeks ago and the present they feel in beholding the dignified assumption of royalty, by the Prince, that in spite of terribly adverse influences, he asserts in his character that he was born to rule, and is every inch a King. ${ }^{79}$

Some of the business element in Hawai'i liked him because he was the candidate who most likely would return voting rights to the people; then the missionary party could presumably obtain more representation in the government. Second, the newspapers' coverage of the entire election period demonstrates that preliminary declarations for Lunalilo in mass meetings organized to mourn Kapuāiwa's passing were early indicators of the wishes of the majority of the kingdom. The newspapers serve as records that confirm that the people backed Lunalilo prior to his mandate for a plebiscite, and the newspapers' reports of maka'āinana certainty for Lunalilo in districts throughout the kingdom may have persuaded wavering voters. ${ }^{80}$

How did newspaper editors use the press? Lunalilo's promise to reinstall Kauikeauoli's constitution appealed to those in the business element in Hawai' $i$ in particular, and the $P C A$ showed its support of the prince. The PCA held the new king to his promise: "We cannot believe that if [Lunalilo] had issued a manifesto pledging himself to maintain the [1864] Constitution and reign in the spirit of the late government, we should have witnessed this auspicious welcome." ${ }^{81}$ In addition, in April 1873, just months after the election, the only two Hawaiian-language newspapers merged to become Ka Nupepa Kuokoa Me Ke Au Okoa I Huiia, but soon Whitney ended $\mathrm{Ke} A u$ Okoa to solely publish Kuokoa. In Kuokoa, Whitney was publishing his support for Lunalilo in the native language, but most likely backed the prince for business reasons. Whitney, along with the missionary party, supported annexation, and on January 27, 1873, just weeks after Lunalilo became king, Whitney approached Lunalilo with another reciprocity plan. ${ }^{82}$ Months later, Lunalilo terminated that plan due to native opposition to it. In short, the sentiments of a newspaper printed in the native language were complex. Support for Lunalilo in the PCA was fueled also by a desire for control of the throne. The motives of each newspaper therefore varied, regardless of its language. 
The newspapers also permanently recorded maka'āinana engagement in the kingdom's first ever plebiscite. It is important to note that while Lunalilo's victory was seemingly assured well before the January 1 election, a large number of voters still made it a point to turn out at the polls. Casting their votes for Lunalilo was important to those people, and overall, voting was a right they took seriously even if it was simply ceremonial. What was the exact voter turnout at that election? Albert F. Judd remembered that the election result was "unlooked for and something wonderful" 83 and altogether the newspapers reported that thousands turned out and anticipation was high. In Lunalilo's announcement of the January 1 plebiscite, he invited "all male subjects of the kingdom" 84 twenty and older ${ }^{85}$ to vote irrespective of property and income. Although Lunalilo's predecessor, Kapuāiwa, had placed qualifications on male voters through the 1864 Constitution, Lunalilo lifted those restrictions so that all men were eligible to vote on January 1 . It is known that most nineteenthcentury native maka'āinana maintained a steady and informed engagement in politics, and thus would have likely been invested in that election. But population totals of that period still suggest that thousands of men did not vote for one reason or another. Thomas G. Thrum's Hawaiian Almanac E Annual for 1875 provides census totals taken on December 27, 1872, just days prior to the plebiscite, in major districts throughout the kingdom. According to Thrum there were more than 7,000 men in Honolulu, more than 2,200 men in Hilo, about 2,ooo men in Wailuku, and some 1,500 men in Lahaina. ${ }^{86}$ Kuokoa printed the plebiscite votes, and Lunalilo won 3,049 votes in Honolulu, 974 votes in Hilo, 729 votes in Wailuku, and 584 votes in Lahaina. ${ }^{87}$ Fewer than half of the men in all of those major districts voted. Perhaps there was limited accessibility to polls. For example, the polling booth in Honolulu may have been the closest one for the residents of Lā'ie. Perhaps maka'āinana lacked sufficient time to prepare the polls for the plebiscite. The low voter turnout in the kingdom's first plebiscite is surprising in light of the newspapers' reports of the day-to-day, seeming widespread, and unanimous support for Prince Lunalilo. Could the newspapers have exaggerated the kingdom's enthusiasm?

The election was certainly unique as it was the first time the people had to wait to see if their representatives voted according to their will, 
and on the day after the election, the newspapers boasted that the representatives had listened to the people's voice. Above all, the election was a triumph for the Hawaiian nation because the people had a say—they could trust their lunamaka'āinana. In particular, realizing that lunamaka'āinana would correctly represent the people's votes, when the 1864 Constitution simply stated that the legislators were to elect an ali' $i$ as successor, assured Native Hawaiians that they had a firm hold on their kingdom's governing powers and independence. This guarantee was vital, as annexation of Hawai' $i$ to the United States became an increasing threat to Kānaka Maoli. Ke Au Okoa celebrated native victory with this acclaim:

E ke Aupuni a me ka Lahui Hawaii, e hauoli lanakila ponoi maoli kakou [...] a kakuaia hoi na Lunamakaainana pakahi, a pau loa, me ke aloha alii, ke aloha aina, ke aloha maluhia, a me ke aloha puniole hoi i ko oukou mau leo, a me ka maliu a hoolohe hoi i ka oukou mau kauoha paa ia lakou, e na Makaainana aloha alii o na makani olu koha'i o Hawaii makamae nei! $!^{88}$

[O Hawaiian Kingdom and Nation, we are truly, joyfully victorious [ ... ] and all the Representatives were indeed individually bound together in chiefly love, love for the land, a peaceful respect, and an overwhelming regard for your voices, in heeding and listening to your firm charges to them, o chiefly-loving people of the fair winds of precious Hawai' $i$ i!]

That Lunalilo's ascension to the throne was realized through overwhelming public support is a matter of historical record, a reality recorded in simple, unambiguous terms in the English-language press of the day. However, broadening the scope of examination through the inclusion of Hawaiian-language newspapers brings into sharp relief a bittersweet irony: Lunalilo was brought to power by a confluence of two distinct and contradictory forces-Kānaka Maoli who held true to the belief that royal lineage equated to divine sanction and was alone a guarantor of kingly potential, and non-native businessmen seeking greater political influence through the overturning of the 1864 Constitution and the further establishment of democratic rule. In the end, both were vindicated. Lunalilo rose above his frailties and served ably as Hawai'i's first elected mō'ì until his passing on February 3, 1874 . 


\section{Notes}

${ }^{1}$ W. D. Alexander, ed., "Correspondence Relating to the Last Hours of Kamehameha V. Documents," Sixth Annual Report of the Hawaiian Historical Society for the Year I 898, 14-15.

2 Ralph S. Kuykendall, The Hawaiian Kingdom, volume 2, 1854-1874, Twenty Critical Years (Honolulu: U of Hawaii P, 1953) ignores Hawaiian-language newspapers and their reports, which elucidated native support for Lunalilo. The term maka'āinana once signified non-chiefly status, or that of a "commoner." With the advent of nationhood, the term was used to refer to a citizen of the nation, whether indigenous Hawaiian or an immigrant who had applied for and been granted full citizenship. It can be confusing, but many historical references to "Hawaiians" were regarding citizenship rather than bloodline.

3 "Lunalilo, the Sixth King of Hawaii. By A. Francis Judd. Contemporary Letters," Forty-Fourth Annual Report of the Hawaiian Historical Society for the Year 1935, 28.

4 "Lunalilo, the Sixth," 28.

5 "Lunalilo, the Sixth," 33.

6 "Lunalilo, the Sixth," 27-35. 28.

${ }^{7}$ Lili'uokalani, Hawaii’s Story by Hawaii’s Queen (Honolulu: Mutual, 1990) 37.

${ }^{8}$ Lili'uokalani says that she and Mrs. Fanny Young, Queen Emma's mother, were other possible successors. See Lili‘uokalani, Hawaii’s 35 .

${ }^{9}$ Kapualokeli' 'ili'iokalani M. K. Renaud, "He Ali'i Koho Mua: A Glimpse into the Life of King William Charles Lunalilo," Master's Thesis. (University of Hawai'i at Mānoa, 2012) 2.

${ }^{10}$ Lili'uokalani, Hawaii’' $36-37$.

11 The terms Kānaka 'Ōiwi (Native Person), Kānaka Maoli (Indigenous Person), and Native Hawaiian refer to the indigenous people of the Hawaiian Islands and their descendants.

12 In the mid-1 87 os, the views of $H G$ clashed with those of King Kalākaua, and then the paper began to support the mō'î̀'s opposition.

13 "Ko Kakou Kulana i keia Wa," Ka Nupepa Kuokoa Dec. 2, $1872,2$.

14 "Chamberlain's Notice" of December 12, 1872, states that from that date until two weeks after Kapuāiwa's funeral the court, government officials, and public will go into full mourning. See PCA Dec. 12, $1872,2$.

15 "Ma ka Auwina La Poaha," Ke Au Okoa Dec. 19, 1872, 3.

16 "He Halawai Koho Moi!" Ka Nupepa Kuokoa Dec. 21, 1872, 2 \& "Halawai Makaainana Nui,” Nupepa Kuokoa Dec. 28, 1872, 2.

${ }^{17}$ Kapuāiwa had been ill for months, and rumors of his approaching death circulated throughout the kingdom. See "Death of the King," PCA, Dec. 14, 1872. 2. Chronicling America: Historic American Newspapers.

${ }^{18}$ Jonathan Kay Kamakawiwo'ole Osorio. Personal interview. Nov. 4, 2014.

19 "The Plebiscitum," PCA Dec. 21, 1872, 2.

20 "The Published Address of His Highness Prince Lunalilo," PCA Dec. 21, $1872,2$.

21 "Halawai Mau ma Kaumakapili," Ka Nupepa Kuokoa Dec. 21, $1872,2$. 
22 "Ua Loaa Mai ia Makou," Ka Nupepa Kuokoa Dec. 26, 1872, 3 \& "Na Halawai Koho Moi," Ka Nupepa Kuokoa Dec. 28, 1872, 2.

23 "No ko Kakou Moi Hou," "He Pepa Hoopii," "E Kupaa na Makaainana!" ; "Ke Hele Nei," "He Halawai Koho Moi!," "Nu Hou Kuloko: Oahu," Ka Nupepa Kuokoa Dec. 21, $1872,2$.

24 "I ka Mea Kiekie ke Alii W. C. Lunalilo," Ke Au Okoa Dec. 19, 1872, 2.

25 "The Prince," PCA Jan. 4, $1873,2$.

26 "He Halawai Koho Moi!"

27 "The Legislative Assembly Meets Today," HG Jan. 8, 1873 , 2. Chronicling America: Historic American Newspapers.

28 "The Prince."

29 "Eia ka Oiaio a me ka Pololei Maoli! O Ke Keiki Alii ka Mea Kiekie, William C. Lunalilo ka Moi, a Oia no ke Noho ma ka Noho Alii a me ka Lei Kalaunu o ke Aupuni," Ka Nupepa Kuokoa Dec. 28,1872, 1.

30 "Na Kumu Kupono e Lilo io ai i Moi," Ka Nupepa Kuokoa Dec. 28, 1872, 2.

31 This reference explains that the mō'i officially designated a prince, and that title changed with each sovereign. Only some ali 'i were legally designated as princes or princesses. In "Princes and Chiefs Eligible to be Rulers," The Polynesian Jul. 20, 1844, 1 Chronicling America, Kauikeaouli, Kamehameha III, named Alexander Liholiho heir apparent while Kapuāiwa, Lunalilo, Kalākaua, and others were princes and chiefs eligible to become mō'î. In 1866 , just after Princess Victoria Kamāmalu, heir to the throne, died, the PCA reported that the "male Aliis" eligible for the throne were, among others, Lunalilo and Kalākaua (See "The Untimely Death of the Princess Royal," PCA Jun. 2, 1866, 2). The dates for Lunalilo's and Kalākaua's title designations under Kapuāiwa have not yet been determined, however the newspapers printed during Kapuāiwa's reign address Lunalilo as Prince and His Highness and Kalākaua as Mr. or Honorable (See "Restoration Day," PCA Aug. 5, 1865, 2 \& "Proceedings of the Legislative Assembly-1868," HG Jun. 10, 1868, 1).

32 "Koho Balota," Ke Au Okoa Jan. 2, $1873,2$.

${ }^{33}$ David Kalākaua,"E O‘u Pokii! E O‘u Lahui Kanaka mai ka Po! E Ala! Eia ka Leo!" broadside, Dec. 28, 1872 . AH.

34 "E O‘u Pokii!"

35 "E O'u Pokii!"

36 "The Plebiscitum," PCA Dec. 21, $1872,2$.

37 "The Vote at Waialua," PCA Jan. 4, 1873, 3.

38 Jonathan Kay Kamakawiwo'ole Osorio, Dismembering Lāhui: A History of the Hawaiian Nation to 1887 (Honolulu: University of Hawai'i P, 2002) 144.

39 "Shall We Drift?" PCA Dec. 14, 1872, 2; "Very Naturally," PCA Dec. 14, 1872, 2 \& "The Interregnum," PCA Dec. 14, 1872, 3 .

40 "Communicated: The Organic Law,"; "Shall We Drift?"; "For the P. C. Advertiser. Mr. Editor," PCA Jan. 4, 1873, 3; "Communicated: The Leading Article,"; "Communicated: Mr. Editor-The Able Article of the Gazette," PCA Jan. 11, 1873, 3 \& "Our Correspondent Who Signs Himself with ** Writes Very Sensibly,” PCA Jan. 11, 1873, 2. 
41 "Very Naturally."

42 "The Prince"; Ke Au Okoa did not cover the proceedings of the plebiscite.

43 "The Prince," PCA Jan. 4, $1873,2$.

44 "The Prince," PCA Jan. 4, 1873, 2.

45 "The Prince," PCA Jan. 4, $1873,2$.

46 "The Prince," PCA Jan. 4, 1873, 2.

47 "Ke Koho Balota Moi," Ka Nupepa Kuokoa Jan. 1 1, $1873,2$.

48 "Ua Hoohauoli Nui ia ka Puuwai," Ke Au Okoa Jan. 2, $1873,2$.

49 "The Legislative Assembly Meets Today," HG Jan. 8, $1873,2$.

50 "Ke Koho Moi Ana! Lanakila ka Leo o na Makaainana. Ke Koho Lokahi Loa ia ana o ke Keiki Alii, ka Mea Kiekie William Charles Lunalilo, e ka Ahaolelo o ko Hawaii Pae Aina!!” Ke Au Okoa Jan. 9, $1873,2$.

51 "Lanakila ka Moi," Ka Nupepa Kuokoa Jan. 11, 1873, 2; "Very Thoughtful and Appropriate," PCA Jan. 1 1, 1873, 2; and Kuykendall Hawaiian Kingdom volume $2,244-245$.

52 "Ke Koho Moi Ana!"

53 "Lanakila ka Moi."

54 "Ke Koho Moi Ana!"

55 "Ke Koho Moi Ana!"

56 "After the Election of the King had been Declared," PCA Jan. 1 1, $1873,2$.

57 "After the Election."

58 "Ke Koho Moi Ana!"

59 "Ke Koho Moi Ana!"

60 "The Prince," PCA Jan. 11, $1873,4$.

61 "Double Dealing on Kauai," PCA Jan. 1 1, $1873,4$.

62 "The Prince," PCA Jan. 1 1, 1873,4 .

63 "Ka Halawai Koho Moi o na Makaainana ma ka Apana o Hanalei Kauai." Ke Au Okoa Jan. 9, $1873,1$.

64 "The Accession to the Throne," PCA Jan. 1 1, 1873 , 3.

65 "From the Gazette Extra, January 9th: His Majesty, the King," $H G$ Jan. 15, $1873,2$.

66 "From the Gazette."

67 "From the Gazette."

68 "From the Gazette."

${ }^{69}$ In 1860 , Lunalilo won a contest sponsored by Kamehameha IV by composing the Hawaiian lyrics to the tune of "God Save the King." It is said that he wrote it in $15^{-20}$ minutes. Lunalilo donated the \$10 prize money to the Queen's Hospital. See "Follow Up to Hawaiian National Hymn, 1862," https://nupepa -hawaii.com Apr. 29, 2013. "News of Hawaii Nei," Ka Nupepa Kuokoa Feb. 15, 1862, 2. Also $H G$ Feb. 1 1, 1862 \& F 3/2/1874.

70 "Lunalilo is King," PCA Jan. 1 1, $1873,2$.

${ }^{71}$ The business element in Hawai' $i$ included non-native subjects and foreign-born men who became businessmen. They were able to vote in the January 1, 1873 election.

72 "Lunalilo, the Sixth," 28. 
${ }^{73}$ Lili‘uokalani, Hawaii’s 37.

${ }^{74}$ Lili'uokalani, Hawaii's 37.

${ }^{75}$ Lili“uokalani, Hawaii’s $37-38$.

76 "Lunalilo, the Sixth," 34.

77 A denizen in this instance was a citizen of another country, who received all the rights, privileges, and immunities of a Native Hawaiian from the king, without, however, renouncing allegiance to his country of origin.

78 Osorio. Personal interview.

79 "A History of the Events Leading to the Election of King Lunalilo" explains that some voters were uncertain who to elect on Jan. 1. Lunalilo (Honolulu, Jan. 15, 1873) 3 .

80 "A History."

81 "Lunalilo is King."

82 George Chaplin. Presstime in Paradise: The Life and Times of The Honolulu Advertiser, I856-1995 (Honolulu: U of Hawai'i P, 1998) 69.

83 "Lunalilo, the Sixth," 28.

84 "William C. Lunalilo, Son of Kekauluohi, the Daughter of Kamehameha I., to the Hawaiian People, Greeting," PCA Dec. 21, 1872, 2.

85 "The Published Address of His Highness Prince Lunalilo," PCA Dec. 21, 1872, 2.

86 Thomas G. Thrum, "Census of the Principal Townships of the Hawaiian Islands, Taken December 27, 1872," HAA for $1875,6$.

87 "Ke Koho Balota Moi no na Makaainana Jan. 1, 1873," Ka Nupepa Kuokoa Jan. $11,1873,2$.

88 "Ke Koho Moi Ana! Lanakila ka Leo o na Makaainana. Ke Koho Lokahi loa ia ana ke Keiki Alii, ka Mea Kiekie William Charles Lunalilo e ka Ahaolelo o ka Hawaii Pae Aina!!" Ke Au Okoa Jan. 9, $1873,2$. 
